\title{
Styles of alteration of Ti oxydes of the kimberlite groundmass: implications on the petrogenesis and classification of kimberlites and similar rocks
}

\author{
Jingyao Xu ${ }^{1}$, Joan Carles Melgarejo ${ }^{2}$, Montgarri Castillo-Oliver ${ }^{3}$ \\ ${ }^{l}$ Departament de Mineralogia, Petrologia i Geologia Aplicada, Facultat de Ciències de la Terra, Universitat \\ de Barcelona, Barcelona, Spain, jingyao.xu@ub.edu \\ ${ }^{2}$ Departament de Mineralogia, Petrologia i Geologia Aplicada, Facultat de Ciències de la Terra, Universitat \\ de Barcelona, Barcelona, Spain, joan.carles.melgarejo.draper@ub.edu \\ ${ }^{3}$ ARC Centre of Excellence for Core to Crust Fluid Systems and GEMOC, Department of Earth and Planetary \\ Sciences, Macquarie University, NSW, Australia,montgarri.castillo-oliver@mq.edu.au
}

\section{Introduction}

Ti-minerals as ilmenite, spinels and perovskite are diamond indicator minerals and are important carriers of petrogenetic information. However, in many cases these minerals suffer complex alteration processes during the hydrothermal or supergene late stages of the kimberlite crystallization sequence.

Altered kimberlites occur in the Bastar craton (central India) and the Eastern Dharwar craton (EDC, Southern India) in India. Kimberlite pipes and dikes (around 100 intrusions) from the EDC of southern India are distributed in three distinct fields: 1) the southern Wajrakarur kimberlite field; 2) the northern Narayanpet kimberlite field; and 3) the Raichur kimberlite field (Chalapathi Rao et al, 2013). This study compares the sequences of alteration in samples from two nearby pipes (SK-1 and SK-2, about $1100 \mathrm{~m}$ of distance) from Siddanpalli, Raichur Kimberlite field, EDC, southern India. The emplacement of these kimberlites is assumed to have taken place during the Mesoproterozoic, around 1,1 Ga (Chalapathi Rao et al., 2013).

\section{Mineral textures}

Both kimberlites have similar xenocrysts, mainly consisting of Ti oxides as rutile and ilmenite, scattered in a fine-grained groundmass.

Textures of the primary minerals of the groundmass are also similar in both fields, and grosso modo comprise calcite, apatite, perovskite and altered atoll-shaped spinel group minerals. The abundance of minerals of the serpentine group in the groundmass suggests that members of the olivine group were also common in this in these kimberlites.

Groundmass perovskite (type 1 perovskite) from SK-1 is euhedral, zoned and slightly replaced by anatase following grain borders and small cracks. Identity of anatase was confirmed by microRaman spectroscopy, and its spectrum was compared with that of anatase altering perovskite in carbonatites (Pereira et al., 2005). Spinel group minerals in groundmass are strongly altered to serpentine, calcite, magnetite and cryptocrystalline Ti-rich hydrogarnets.

Groundmass perovskite (type 1 perovskite) from SK-2 is euhedral to subhedral and it has oscillatory zoning. In addition, a second perovskite generation (type 2 perovskite, euhedral) replaces the atoll spinel of groundmass along with Ti-rich hydrogarnets, calcite and serpentine.

Type 1 perovskite from SK-2 is partially or nearly totally replaced by kassite $\left[\mathrm{CaTi}_{2} \mathrm{O}_{4}(\mathrm{OH})_{2}\right]$ accompanied by abundant aeschynite-(Ce), ideally $\left[(\mathrm{Ce}, \mathrm{Ca}, \mathrm{Fe}, \mathrm{Th})(\mathrm{Ti}, \mathrm{Nb})_{2}(\mathrm{O}, \mathrm{OH})_{6}\right]$. Identity of kassite instead of cafetite $\left(\mathrm{CaTi}_{2} \mathrm{O}_{5} \mathrm{H}_{2} \mathrm{O}\right)$ was confirmed by comparing the kassite Raman spectrum from the SK-2 kimberlite with the kassite spectrum published by Martins et al. (2014). SK-2 perovskite may also be replaced by Mn-rich ilmenite along small cracks. Ilmenite and magnetite xenocrysts from SK-2 may be replaced by a sequence of typical groundmass minerals, as ulvöspinel and type 2 perovskite; on its turn, this perovskite may be replaced by anatase. 


\section{Mineral chemistry}

Spinel-group minerals from groundmass of both kimberlites have compositions in the ulvöspineltitanomagnetite domain. However, they are strongly altered and the restitic cores may be seldom enriched in $\mathrm{Zn}(0,1-2,0 \mathrm{wt} . \% \mathrm{ZnO}$ in SK-1 and 0-7,5 wt.\% $\mathrm{ZnO}$ in SK-2).

The composition of type 1 groundmass perovskite is similar for both kimberlites. Cores are slightly enriched in REE (4,9-6,2 wt.\% $\sum \mathrm{REE}_{2} \mathrm{O}_{3}$ in the cores $v s$ 1,9-2,8 wt.\% $\sum \mathrm{REE}_{2} \mathrm{O}_{3}$ in the rims in SK-1; 5,1- 5,5 wt.\% $\sum \mathrm{REE}_{2} \mathrm{O}_{3}$ in the centers and 0,9-2,6 wt.\% $\sum \mathrm{REE}_{2} \mathrm{O}_{3}$ in the borders in SK-2). Nb is also slightly enriched in the cores compared to the rims $\left(0,6-1,1 \mathrm{wt} \% \mathrm{Nb}_{2} \mathrm{O}_{5}\right.$ in the cores and $0,4-0,6 \mathrm{wt} . \%$ $\mathrm{Nb}_{2} \mathrm{O}_{5}$ in the rims in SK-1; 0,5-0,8 \% $\mathrm{Nb}_{2} \mathrm{O}_{5}$ in the cores and $0,4-0,6$ wt. $\% \mathrm{Nb}_{2} \mathrm{O}_{5}$ in the rims in SK-2). Perovskite 1 in both kimberlites has $\mathrm{FeO}$ contents ranging 0,9-1,6 wt.\%.

Type 2 perovskite from the SK-2 kimberlite has different composition than the type 1 perovskite. It is poor in $\mathrm{REE}\left(<1 \mathrm{wt} . \% \sum \mathrm{REE}_{2} \mathrm{O}_{3}\right)$ and $\mathrm{Nb}\left(<0,1 \mathrm{wt} . \% \mathrm{Nb}_{2} \mathrm{O}_{5}\right)$, but it has higher Fe contents $(2,4-3,5 \mathrm{wt} . \%$ $\mathrm{FeO})$ than type 1 perovskite.

Kassite replacing type 1 perovskite has a stoichiometric composition, whereas the associated aeschynite tends to concentrate LREE and, to a lesser extent, $\mathrm{Nb}$.

The aeschynite-(Ce) produces the next average structural formula: $\left(\mathrm{Ca}_{0,39} \mathrm{Ce}_{0,33} \mathrm{La}_{0,13} \mathrm{Nd}_{0,12} \mathrm{Pr}_{0,04}\right) \sum$ ${ }_{1,01}\left(\mathrm{Ti}_{1,82} \mathrm{Nb}_{0,07} \mathrm{Fe}^{3+}{ }_{0,02} \mathrm{Zr}_{0,02}\right) \sum_{1,93}(\mathrm{O}, \mathrm{OH})_{6}$. Therefore, the aeschynite group minerals from SK-2 kimberlite are extremely poor in $\mathrm{Nb}, \mathrm{U}$ and $\mathrm{Th}$ when compared to similar minerals typically occurring as metamictic phases in carbonatites and granitic pegmatites. However, their compositions are similar to those of the late Ti-REE minerals described in the Iron Mountain kimberlite field (Mitchell and Chakhmouradian, 1998).

Ti-rich hydrogarnets from the SK-2 kimberlite were analyzed by EMP while those from the SK-1 pipe are too small to be analyzed. The Ti-rich hydrogarnets replacing Ti-rich spinels from the SK-2 have intermediate compositions between morimotoite, "hydroschorlomite" and Ti-rich "hydroandradite".

\section{Discussion and conclusion}

Perovskite is a principal host of LREE in undersaturated ultramafic and alkaline rocks. However, perovskite may be unstable in $\mathrm{CO}_{2}$-rich fluid environments characteristic of some carbonatites and kimberlites worldwide (Mitchell and Chakhmouradian, 1998). Perovskite replacement in kimberlites is not common, but may include kassite, anatase and titanite along with calcite, ilmenite and unidentified LREE-Ti oxides (Mitchell and Chakhmouradian, 1998; Martins et al., 2014).

The subsolidus history of the studied Indian kimberlites has important differences, and in particular the alteration of perovskite is more developed in SK-2. The alteration process took place under different fluid/rock ratios in each kimberlite, in a relatively closed system. Under these conditions, Ti-rich minerals are unstable and, in particular, Ti-rich spinels are easily replaced in both kimberlites by mixtures of Ti-rich hydrogarnets, calcite and serpentine. A relatively low $\mathrm{SiO}_{2}$ and high water activities were necessary to both avoid the crystallization of titanite and favour the crystallization of hydrogarnets. Slight replacement of perovskite by anatase in SK-1 could be indicative of a decrease of temperature under conditions of medium to high $\mathrm{f}\left(\mathrm{CO}_{2}\right)$, following the experimental data by Martins et al. (2014). However, the same experimental data suggest that the strong replacement of perovskite by kassite in SK-2 needs a high $\mathrm{f}\left(\mathrm{H}_{2} \mathrm{O}\right)$ and a low activity in alkalis. The LREE-rich perovskite is more unstable during these processes than pure end-member perovskite. Therefore, aeschynite-(Ce) inherits the composition of the replaced LREE-bearing perovskite cores, and it is as Nb-poor as are these cores. 
The occurrence of abundant Ti-rich garnets in the groundmass of the rock could suggest an aillikitic affinity during a preliminary examination, based on the IUGS rock classification (Tappe et al., 2005). Similar occurrences in Indian pipes have been used to classify the rocks as orangeites (Dogre et al., 2016). However, the Ti-rich hydrogarnets studied in the present work are produced by very late hydrothermal processes and therefore they cannot be representative of the magma composition. Therefore, attention must be paid to the position of Ca-Ti-garnet in the mineral sequence before using it to classify the rock based on its occurrence.

Perovskite commonly crystallizes directly from the kimberlite magma (Mitchell, 1986) and therefore it is one of the most used minerals for U-Pb dating of kimberlites and carbonatites (Cox and Wilton, 2006; Castillo-Oliver et al., 2016). However, our petrographic studies demonstrate the limitations of the use of groundmass perovskite for such purpose. Our data shows that two types of perovskite occur in the studied Indian kimberlites, being the first crystallized directly from the kimberlite magma, but the second from hydrothermal origin. Furthermore, primary perovskite may be strongly altered to secondary minerals that may redistribute REE and potentially, $\mathrm{U}, \mathrm{Pb}$ and $\mathrm{Th}$. Therefore, accurated petrographic analyses are necessary before proceeding to sort geochronological data with perovskite.

\section{Acknowledgments}

This research was supported the AGAUR 2014SGR01661 of the Generalitat de Catalunya and a FI grant to J. Xu (coded FI_B 00904) sponsored by the Departament d'Educació i Universitats de la Generalitat de Catalunya. The authors also acknowledge the Servei de Làmina Prima (thin section preparation laboratory) and the Centres Científics i Tecnològics de la Universitat de Barcelona (CCiTUB) for the assistance with SEM-BSE-EDS study (Dr. F. J. García-Veigas, D. Artiaga) and EMP analyses (Dr. Xavier Llovet).

\section{References}

Castillo-Oliver M, Galí S, Melgarejo JC, Griffin WL, Belousova E, Pearson NJ, Watangua M, O'Reilly SY (2016) Trace-element geochemistry and U-Pb dating of perovskite in kimberlites of the Lunda Norte province (NE Angola): petrogenetic and tectonic implications. Chem. Geol. 426: 118-134

Chalapathi Rao NV, Wu FY, Mitchell RH, Li QL, Lehmann B (2013) Mesoproterozoic U-Pb ages, trace element and $\mathrm{Sr}-\mathrm{Nd}$ isotopic composition of perovskite from kimberlites of the Eastern Dharwar craton, southern India: distinct mantle sources and a widespread 1.1 Ga tectonomagmatic event. Chem Geol. 353:48-64

Cox RA, Wilton, DHC (2006) U-Pb dating of perovskite by LA-ICP-MS: An example from the Oka carbonatite, Quebec, Canada. Chemical Geology 235: 21-32

Dongre AN, Viljoen KS, Chalapathi Rao NV, Gucsik A (2016) Origin of Ti-rich garnets in the groundmass of Wajrakarur field kimberlites, southern India: insights from EPMA and Raman spectroscopy. Mineralogy and Petrology 110: 295-307

Martins T, Chakhmouradian AR, Medici L (2014) Perovskite alteration in kimberlites and carbonatites: the role of kassite, $\mathrm{CaTi}_{2} \mathrm{O}_{4}(\mathrm{OH})_{2}$. Phys Chem Minerals 41: 473-484

Mitchell RH (1986) Kimberlites: Mineralogy, Geochemistry, and Petrology. Plenum Press, New York. $442 \mathrm{pp}$

Mitchell RH, Chakhmouradian AR (1998) Instability of perovskite in a $\mathrm{CO}_{2}$-rich environment: examples from carbonatite and kimberlite. Can. Mineral. 36:939-952

Pereira VP, Conceição RV, Formoso MLL, Pires AC (2005) Alteration of perovskite to anatase in silicaundersaturated rocks of the Catalão-1 carbonatite complex, Brazil: a raman study. Rev. Brasil. Geociências 35: 239-244

Tappe S, Foley SF, Jenner GA, Kjarsgaard BA (2005) Integrating ultramafic lamprophyres into the IUGS classification of igneous rocks: rationale and implications. J. Petrol. 46: 1893-1900 